\title{
Mitigating Price Effects with a Housing Linkage Fee
}

\author{
John A. Henning, Jr. $\dagger$
}

Real estate developers, especially in rapidly-growing areas, are subject to a panoply of land dedication requirements and "impact fees." The stated purpose of these exactions is not to redistribute wealth from landowners to the public but to regulate the externalities that development imposes on the public. However, in this Comment the author argues that a new breed of exactions, known as housing "linkage fees," crosses the boundary between regulatory exactions and taxes. After briefly outlining the history of development exactions, the author discusses externality theory and shows how courts have implicitly applied it to exactions. Then he argues that housing linkage fees fail to address a true externality, and so are redistributive. He recommends that courts and legislatures explicitly adopt externality analysis so as to preclude the use of the police power to accomplish redistributive ends.

\section{INTRODUCTION}

With their taxing powers circumscribed by political reality, if not outright voter "tax revolts" like California's Proposition $13,{ }^{1}$ mumicipahties continually search for new revenue sources to fund public facilities and services. One innovation that has gained widespread acceptance is the real estate development exaction-a dedication of land or payment of an "impact fee" required as a condition of subdivision or development approval. ${ }^{2}$ Exactions provide funds for roads, parks, schools, and a host of other capital facilities, and are justified on the theory that property taxes paid by the eventual owners of new residential and commercial developments do not approximate the burden they place on such facilities. $^{3}$ In California, land dedications have also been used to mitigate the

$\dagger$ B.S. 1986, Syracuse University; Master of City Planning 1990, University of California, Berkeley; third-year student Boalt Hall School of Law, University of California, Berkeley.

1. Passed by initiative in 1978, this neasure placed strict limits on ad valorem property taxes and most other non-property taxes. CAL. CoNST. art. XIII A (1978, amended 1986). Several other states have passed similar measures. See Susskind \& McMahon, Reframing the Rationale for Downtown Linkage Programs, N.Y. AF., Wimter 1988, at 203, 206.

2. According to a recent study, $88 \%$ of cities and counties inpose dedication requirements, while 58\% impose "cash" exactions. Weschler, Mushkatel \& Frank, Politics and Administration of Development Exactions, in DEVELOPMENT EXACTIONS 27 (J. Frank \& R. Rhodes eds. 1987).

3. For a thorough discussion of the use of, and justification for, inpact fees, see T. SNYDER \&

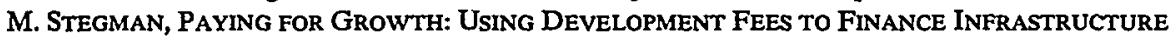
(1986). 
negative effects of beachside development on public access to the shoreline. ${ }^{4}$

Municipalities prefer to raise revenue through development exactions rather than through taxes. The power to tax is tightly circumscribed by state law, while development exactions, because they are imposed under the pohice power, are generally himited only by the requirement that they be rationally related to a legitimate interest of the inumicipahity. 5 In addition, development exactions may be politically expedient, since they are borne largely by unpopular groups such as developers and immigrating residents instead of by the population as a whole.

Perhaps the most aggressive apphication of development exactions to date is "linkage"-the levying of fees on downtown office development to subsidize low- and middle-income housing. ${ }^{6}$ Instituted in San Francisco, ${ }^{7}$ Boston, ${ }^{8}$ and a handful of other cities, hinkage progranis find support in studies that link development to an increased need for housing by showing that new workers increase the deinand for, and thus the price of, existimg housing. ${ }^{9}$

Unlike other development exactions, housing linkage programs are not valid exercises of the pohice power. The pohice power is properly exercised in the land-use arena when a proposed developnient would encroach on the entitlements or property of others and produce an "externahty."10 Indeed, niost developinent exactions are designed to

4. See infra notes 130-38 and accompanying text. The leading case regarding this use of exactions is Nollan v. California Coastal Commission, 483 U.S. 825 (1987).

5. See infra notes 105-15 and accompanying text.

6. For an excellent layperson's discussion of the San Francisco linkage program, see Goetz, Office-Housing Linkage in San Francisco, 55 J. AM. PLAN. A. 66 (1989). A thorough, if somewhat dated legal analysis is contained in Diamond, The San Francisco Office/Housing Program: Social Policy Underwritten by Private Enterprise, 7 HARv. ENVTL. L. REv. 449 (1983). Case studies of seven linkage programs are presented in G. McMahon, L. Susskind, E. Tohn, S. Rolley \& J. Rustin, Reframing the Rationale for Downtown Linkage Programs: New Approaches to Negotiated Development (Harvard Law School Program on Negotiation Working Paper 86-2, July 1986). For a recent survey of linkage programs, see Porter \& Lassar, The Latest on Linkage, 47 URB. LAND, Dec. 1988 , at 7 .

7. San francisco, Cal., Planning Code $\$ 313$ (1985).

8. Boston, MAss., ZoNing CODE, art. 26 (1983), amended by Boston, Mass., Zoning CODE, art. 26A (1986).

9. See, e.g., REChT HAUSRATH \& Assocs., SUMMARY OF THE ECONOMIC BASIS FOR AN Office-Housing Production Program (July 19, 1984) (San Francisco); J. Kayden, K. Case \& R. Pollard, The Linkage Between Office Development and Housing Costs in the City OF BOSTON (Jan. 1986).

10. D. Hagman \& J. Juergensmeyer, Urban Planning and Land Development CoNTROL LAw 284 (1986). In the land use arena, for example, classic "Euclidean" zoning has been widely used to separate noisy industrial uses from quiet residential neighborhoods. Village of Euclid v. Ambler Realty Co., 272 U.S. 365, 394 (1926) (detailing some of the legitimate purposes of "Euclidean" zoning). For a discussion of the externality analysis underlying land-use regulation, see Dunham, A Legal and Economic Basis for City Planning, 58 Colum. L. REv. 650 (1958). 
mitigate or eliminate encroachments on public entitlements and property. Housing linkage programs, meanwhile, do not address such encroachments, but merely mitigate the effects of office development on participants in a competitive private housing market. ${ }^{11}$ Thus, they are redistributive in nature and act as taxes.

In cases involving development exactions, both federal and state courts have obscured the externality theory underlying exactions, perhaps because the externalities are not readily identifiable. This trend is apparent in the Supreme Court's first development exactions case, Nollan v. California Coastal Commission. ${ }^{12}$ The Nollan Court focused on whether the plaintiffs' beachside development would 'substantially impede" the state's interest in preserving the public's visual access to the beach, and whether the required dedication of a lateral easement across the beach would "substantially advance" that interest. ${ }^{13}$ The state courts have applied a similar analysis, requiring a nexus between the exaction and a "burden" created by the developinent. Most of these courts, however, have also required that the exaction provide some "benefit" or "service" to the affected development. ${ }^{14}$

A more productive judicial approach would be to determine whether an exaction effectively reduces or eliminates an externality that a developinent would otherwise impose on the public. Indeed, an miplicit externality analysis already pervades most exactions cases. This analysis coines into focus when we recognize that the courts have miphicitly identified two types of public entitlements subject to encroachment by private development: (1) the entitlement to miplied negative easements ${ }^{15}$ on private land, and (2) the entitlement to congestion-free public facilities. Encroachment by development on these entitlements creates externalities, which may be eliminated by the miposition of exactions.

Direct mitigation of the negative effect can effectively eliminate the externahity. For example, applying the proceeds of a road mipact fee to

11. See infra text accompanying notes 211-13.

12. 483 U.S. 825 (1987).

13. See infra text accompanying notes $105-10$.

14. See, e.g., Grupe v. California Coastal Comm'n, 166 Cal. App. 3d 148, 176-77, 212 Cal. Rptr. 578, 596-97 (1985); Ayres v. City Council of Los Angeles, 34 Cal. 2d 31, 39-41, 207 P.2d 1, 7 (1949); Associated Homebuilders v. City of Walnut Creek, 4 Cal. 3d 633, 640 n.6, 644-45, 484 P.2d 606, 612 n.6, 615-16, 94 Cal. Rptr. 630, 636 n.6, $639-40$ (1971), appeal dismissed, 404 U.S. 878 (1972); Hollywood, Inc. v. Broward County, 431 So.2d 606, 611-12 (Fla. Dist. Ct. App. 1983); Contractors \& Builders Ass'n of Pinnellas County v. City of Dunedin, 329 So.2d 314, 320-21 (Fla. 1976); Land/Vest Properties, Inc. v. Town of Plainfield, 117 N.H. 817, 823, 379 A.2d 200, 204 (1977); Miller v. City of Port Angeles, 38 Wash. App. 904, 911-12, 691 P.2d 229, 234-35 (1984), review denied, 103 Wash. 2d 1024 (1985).

15. An "easement" is an interest im one person's land that is held by another person and that limits the owner's use or enjoyment of his land. Although an easement can be "affirmative," allowing the holder to physically occupy the land, a "negative" easement does not contemplate such occupation. See C. BERGER, LAND OWNERSHIP AND UsE 531-32 (3d ed. 1983). 
expand road capacity will reheve the added congestion caused by the development. A "compensatory" exaction scheme on the other hand, allows the encroachment but compensates the public for the loss it bears. "Compensatory" exactions are more efficient and leave both the public and the developer at least as well off as they would have been under a mitigating exaction. ${ }^{16}$ Still, the courts have resisted compensatory exaction schemes. This reluctance is rooted in the wide latitude municipalities have to define their legitimate interests under the police power. Fearing that mumicipalities might identify a spurious state interest, claim an encroachment, and then require compensation from the landowner, the existimg state and federal tests effectively require that the exaction be used to mitigate the externality directly rather than to compensate the public. ${ }^{17}$

Existing judicial tests thus reflect an implied externality analysis, with inodifications that provide rudimentary protection against the use of the police power to extort development value from landowners. However, the tests do not foreclose the increasing use of exactions such as linkage to mitigate negative effects that are not externalities. An explicit application of externality analysis would close this gap in existing doctrine, and expose linkage fees for what they are: measures designed not to mitigate externalities, but to redistribute wealth-and hence beyond the police power of the mumicipality.

Linkage does not fit into the rubric of existing exaction doctrine because the effect of office development on housing is not a true externality. New housing demand resulting from office development probably does cause the price of rental housing to rise and enables landlords to charge all tenants, including existing ones, higher rents. However, this effect is not an externality, but a "price effect" that results from the shift of wealth from existimg renters to their landlords. ${ }^{18}$ A linkage fee, if spent to provide subsidized housing, compensates the loser in this transfer by redistributing wealth from the office developer to the existing renters.

Because it is redistributive, a linkage fee crosses the boundary separating regulatory fees from taxes, ${ }^{19}$ and should be subject to the more rigorous statutory and constitutional hmitations attendant to a tax.

Part I of this Comment discusses the evolution of traditional development exactions and their relationship to taxes. Externality analysis is explained in Part II. Part III analyzes the legal doctrines applied in

16. See infra text accompanying notes 182-83.

17. See infra text accompanying notes $185-92$.

18. See infra text accompanying notes 211-12.

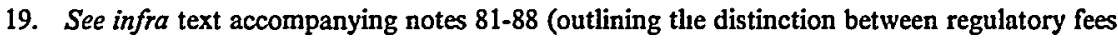
and taxes). 
Nollan and in key state cases in the context of externality theory. Part IV focuses on judicial adaptation of externality theory to protect landowners from land value extortion. Finally, Part V argues that linkage fees fail to address a true externality. The conclusion recommends the incorporation of an explicit externality analysis into judicial and statutory approaches to exactions.

\section{I}

\section{The Evolution of Development Exactions}

\section{A. From Land Dedications to Impact Fees}

Until the early part of this century, inumicipalities used general tax revenues to fund the expansion of public facilities inade necessary by real estate development. ${ }^{20}$ However, a rash of failed subdivisions and the budding city planning inovement led inany cities to require a dedication of land to the public as a condition of subdivision approval. ${ }^{21}$ Because it is an exercise of the general pohice power, a dedication exaction is constrained by the takings clause of the fifth anendment, ${ }^{22}$ which requires compensation to the landowner when property is taken under an invalid exercise of the police power. ${ }^{23}$ Therefore, to avoid a taking, a city must ensure that its exercise of the police power is valid as a reasonable regulation of land use.

To fulfill this requirenent, nlunicipalities initially required dedication only of land within or contiguous to the subdivision, and ouly that necessary for roads, water nuains, and sewerage exclusively serving residents of the subdivision. ${ }^{24}$ Later, exactions were extended to include offsite iniproveinents such as schools and parks tliat would chiefly, but not exclusively, serve the residents of the subdivision. ${ }^{25}$ Dedications for a wide range of purposes were common by $1958 .{ }^{26}$ Today, $88 \%$ of cities

20. Connors \& Meachem, Paying the Piper: What Can Local Governments Require as a Condition of Development Approval?, 1986 INST. ON PLAN. ZoN1NG \& EMINENT DoMA1N § 2.02, at 2-3.

21. See Bosselman \& Stroud, Legal Aspects of Development Exactions, in DevelopMENT Exactions supra note 2, at 70-71; Weschler, Mushkatel \& Frank, supra note 2, at 17-18.

22. U.S. CoNST. amend. V, cl. 4.

23. See Agins v. City of Tiburon, 447 U.S. 255, 260 (1980) ("The determination that governmental action constitutes a taking is, in essence, a determination that the public at large, rather than a single owner, must bear the burden of an exercise of state power in the public interest.").

24. Connors \& Meachein, supra note $20, \S 2.02(1)$, at 2-4 to 2-6.

25. Weschler, Mushkatel \& Frank, supra note 2, at 18. For a discussion of school dedication requirements, see Feldınan, The Constitutionality of Subdivision Exactions for Educational Purposes, 76 DICK. L. REV. 651 (1972). For a discussion of parkland dedication requirements, see Brooks, The Future of Municipal Parks in a Post-Nollan World: A Survey of Takings Tests as Applied to Subdivision Exactions, 8 VA. J. NAT. ResourCes L. 141 (1988).

26. Smith, From Subdivision Improvement Requirements to Community Benefit Assessments 
require land dedication and/or the direct installation of necessary improvements. ${ }^{27}$

Municipahities gradually expanded on the dedication concept. First, they allowed fees in heu of dedication when the plot to be developed was small or otherwise unsuitable for dedication, or when required off-site land was not available. ${ }^{28}$ The " $\mathrm{m}$-heu fees" from a group of subdivisions were then pooled to buy needed land. ${ }^{29}$

Municipalities next began to impose "impact fees," whose revenues were used to imitigate the impact of the development on the community. Impact fees, unlike fees in heu of dedication, were imposed under the zoning power as a condition of discretionary development approvals. ${ }^{30}$ Because they were not precedent to subdivision, impact fees could be imposed on developinents regardless of whether subdivision was contemplated. ${ }^{31}$

Impact fees were first used in the 1920s in Colorado to finance the purchase of water rights for developments. ${ }^{32}$ Later, they were used for other purposes in that state. ${ }^{33}$ When the fabled Proposition 13 tax revolt $^{34}$ passed in California, impact fees gained widespread use there as well. ${ }^{35}$ Today, impact fees pay for land and other costs associated with all manner of capital facilities: water and sewerage, ${ }^{36}$ roads, schools, parks, ${ }^{37}$ fire protection, ${ }^{38}$ and libraries. ${ }^{39}$ A few coinmunities have used such fees to pay for sohid waste facilities, drainage, eniergency inedical service, public buildings, and cenieteries. ${ }^{40}$

Although impact fees are collected in alnost half of the nation's

and Linkage Payments: A Brief History of Land Development Exactions, 50 LAW \& ConTEMP. PROBS. 5, 6 (Winter 1987).

27. Weschler, Mushkatel \& Frank, supra note 2, at 27.

28. Connors \& Meachem, supra note 20, § 2.02(1)(c), at 2-7.

29. Id.

30. Id. $\S 2.02(1)(\mathrm{d})$, at $2-7$ to $2-8$.

31. See id. $\S 2.02(1)(\mathrm{d})$, at 2-8.

32. T. SNYDER \& M. STEGMAN, supra note 3, at 74-75.

33. Id. at 75 .

34. CAL. Const. art. XIII A (1978, amended 1986). Approved as a proposition by the voters, this ineasure limited ad valorem real property taxes to $1 \%$ of cash value at the tine of purchase (§ 1), required supermajority votes for new non-property taxes $(\S 3)$, and required voter approval for "special" loeal taxes (§4).

35. T. SNYDER \& M. STEGMAN, supra note 3, at 75-76.

36. Connection or "hookup" charges are the most common types of water and sewer fees. J. Nicholas, The Calculation of Proportionate Share Impact Febs 3 (1988).

37. Stroud, Legal Considerations of Development Impact Fees, 54 J. AM. PLAN. A. 29, 35-36 (1988).

38. Bosselman \& Stroud, supra note 21 , at 72.

39. J. NicHOLAS, supra note 36 , at 3.

40. Id. Fees are generally assessed on a per-unit basis for residential development, and on a per-square-foot basis for industrial, office, and retail development. Id. at 3-7. Using modern cost accounting, officials attempt to precisely allocate the cost of a facility between subdivisions in order to arrive at the proper fee. For a discussion of how impact fees are calculated, see generally id.; 
municipalities, ${ }^{41}$ they are inost entrenched in rapidly growing suburban communities, especially in "sunbelt" states. ${ }^{42}$ In these areas the traditional method of funding infrastructure, where existing populations fund the expansions necessary for future residents, ${ }^{43}$ can place disproportionate burdens on existing residents. ${ }^{44}$ Furthermore, limitations on taxation $^{45}$ and the resulting decline in the inarketability of municipal bonds ${ }^{46}$ have forced many rapidly growing communities to look to impact fees for infrastructure funding.

Because taxes and police-power exactions are imposed under different constitutional and statutory frameworks, ${ }^{47}$ a inunicipality inust distinguish carefully between the two-using taxes to redistribute wealth from one class of mdividuals to the public generally ${ }^{48}$ and exactions to regulate burdens placed by an activity upon public entitlements and property. ${ }^{49}$ Housing linkage programs, however, have ignored this crucial distinction, employing pohce-power means to achieve redistributive ends.

\section{B. Enter "Linkage"}

The 1980s saw a rapid expansion of office construction in inost major downtowns, fueled by favorable tax treatment and the willingness

Knack, Frank \& Stewart, How Road Impact Fees are Working in Broward County, 1984 PLANNING 24.

41. One survey of 1,000 communities found that $45.4 \%$ of the 220 respondents were using impact fees. Bauman \& Ethier, Development Exactions and Impact Fees: A Survey of American Practices, 50 LAW \& Contemp. Probs. 51, 55, 57 (Winter 1987).

42. See T. SNYDER \& M. STEGMAN, supra note 3, at 77. The states with the greatest number of communities using exactions are California, Florida, Washington, Oregon, Colorado, and Texas, in that order. Weschler, Mushkatel \& Frank, supra note 2, at 25.

43. See T. SNYDER \& M. Stegman, supra note 3, at 5-6 (cities relied primarily on this method of funding through the early 1970 s).

44. See Roberts, Funding Public Capital Facilities: How Community Planning Can Help, in The Changing Structure of Infrastructure Finance 1, 3 (J. Nicholas ed. 1985). Snyder and Stegman note that "intergenerational inequity" is most likely to occur in the funding of facilities requiring "lumpy," or high front-end, capital investınent, such as sewage treatmeut plants, water systems, and inajor transportation facilities. They also note that the likeliliood of inequality increases when the growth rate is higher than the "real" interest rate. T. SNYDER \& M. STEGMAN, supra note 3 , at $39,44-46$.

45. "Tax revolt" measures in several states have limited the ability of numicipalities to fund public serviees through property taxes. See Susskind \& McMahon, supra note 1, at 206-07.

46. Bauman \& Ethier, supra note 41 , at $51-52$.

47. See 4 T. Cooley, The LaW of TaXation $\$ 1784$ (4th ed. 1924).

48. 16 E. MCQUillin, THE LAW OF MUNICIPAL CORPorations $\$ 44.02$ (3d rev. ed. 1979) ("[T]axes are the enforced proportional contributions from persons and property, levied by the state by virtue of its sovereignty for the support of governinent and for all public needs.").

49. For example, road dedication exactions under a zoning ordinance are permissible only when the need for the proposed road is substantially generated by the developinent in question. $8 \mathrm{E}$. MCQUILIIN, supra note 48, § 25.146(a) (3d rev. ed. 1983). 
of financial institutions to fund community developinent projects. ${ }^{50}$ At the saine time, poor and moderate-income inner-city residents were feeling the pinch as federal housing subsidy prograins suffered from drastic cuts, ${ }^{51}$ and the "tax revolt" limited the ability of the states to make up the difference through general tax revenues. ${ }^{52}$

New office construction led to an influx of new office workers, which in turn led to more demand for center-city housing. At the same time, the construction of new housing was increasingly constrained by density himitations ${ }^{53}$ and a heavily regulated planning environment. ${ }^{54}$ Thus, new entrants competed for a limited supply of existing housing, inflating rents and displacing some of the poor tenants. "Gentrification," as the process is called, threatened the rich mix of ethnic and socioeconomic groups that made the city an appealing place to live. ${ }^{55}$

In San Francisco, Boston, and other cities, low-incoine housing activists called for a "linkage" between the booming office sector and housing. The linkage movement was encouraged by a series of trends, including pressure for "inclusionary zoning" in the suburbs, ${ }^{56}$ an increasing use of the environmental review process to mitigate the negative effects of development, ${ }^{57}$ and the rise of "incentive zoning."58 Further, the poitical constituency for housing was strong in these cities, ${ }^{59}$ while the public was relatively ambivalent toward center-city office

50. See Delaney \& Smith, Development Exactions: Winners and Losers, 17 REAL EsT. L.J. 195, 212-13 (1989). The Economic Recovery Tax Act of 1981 provided substantial incentives for office construction. Most of these incentives, however, were repealed by the Tax Reform of Act of 1986. Id.

51. Diamond, supra note 6, at 452-53.

52. See Susskind \& McMahon, supra note 1 , at 206.

53. Porter, The Linkage Issue: Introduction and Summary of Discussion, in DowNTowN Linkages 2, 3 (D. Porter ed. 1985).

54. Diamond, supra note 6, at 454-55.

55. See, e.g., Share \& Diamond, San Francisco's Office Housing Production Program, LAND Use L. \& ZoNING Dig., Oct. 1983, at 4.

56. Brooks, Housing Trust Funds: Lessons from Inclusionary Zoning, in INCLUSIONARY Zoning Moves Downtown 7, 8-11 (1985) (D. Merriam, D. Brower \& P. Tegeler eds. 1985). Inclusionary zoning requires residential developers, usually in well-to-do suburbs, to provide low* and moderate-income housing as a condition of development approval. Thus, "linkage fees," which are imposed on office developers to fund im-city housing, do not strictly qualify as inclusionary. See Alterman, Evaluating Linkage and Beyond: Letting the Windfall Recapture Genie out of the Exactions Bottle, 34 WASH. U.J. URB. \& CONTEMP. L. 3, 25-27 (1988). For a thorough discussion of inclusionary housing programs, see generally A. MALLACH, INCLUSIONARY Housing PROGRAMS: POLICIES AND PRACTICES (1984).

57. See Susskind \& McMahon, supra note 1, at 207-08.

58. Under "incentive zoning," the developer trades concessions for increased development density. New York City pioneered the concept by granting height bonuses to office developers willing to build plazas at street level. See Bosselman \& Stroud, Mandatory Tithes: The Legality of Land Development Linkage, 9 NovA L.J. 381, 386 (1985).

59. Porter, supra note 53, at $2,3$. 
development. ${ }^{60}$

San Francisco became the birthplace of linkage ${ }^{61}$ in $1980 .{ }^{62}$ The San Francisco program required downtown office developers to build housing or contribute toward a citywide housing subsidy fund, under a formula based on the square footage of their developments. ${ }^{63}$ The program gave extra credits for building low and moderate-mcome housing as well as for building larger units. ${ }^{64}$ Still, a common criticism or the original plan was that under the "build" option, developers could satisfy their obligation by constructing luxury, market-rate housing, rather than low- or inoderate-income units. ${ }^{65}$ Partly in response to this criticism, the city revamped the linkage program in 1986, imstituting a mandatory persquare-foot fee of $\$ 5.69$ for all downtown office buildings over 25,000 square feet and earmarking all proceeds for low- and middle-imcome housing. 66

The linkage idea spread. Boston adopted a linkage program in 1983 via an amendment to the zoning code. ${ }^{67}$ Administered by the Boston Redevelopment Authority, ${ }^{68}$ the program is purportedly "voluntary," although participation is a condition of obtaining rezonings, variances, conditional use permits, and other exceptions or amendments. ${ }^{69}$ The

60. A. Mallach, supra note 56, at 187.

61. Actually, Palo Alto, California was the first to require office developers to fund low-incoine housing; although the city did not have a systeınatic program, it negotiated individual contributions through the environmental review process as early as 1978. See Ellickson, The Irony of "Inclusionary Zoning," 54 S. CAL. L. REV. 1167, 1172 \& n.25 (1981).

62. Initially, the San Francisco Planning Commission impleinented its "Office/Housing Production Program" under the mitigation provisions of the California Environmental Quality Act (CEQA), Cal. PUB. Res. CODE \$ 21002.1(b) (West 1986). See Alterman, supra note 56, at 10. After CEQA was amended in 1981 to require mitigation of only physical effects, see CAL. PUB. RES. CODE $\$ 21100$ (West 1986), the program was administered by the city's Planning Commission, under its discretionary power to grant building permits. See Alternan, supra note 56, at 10. For an excellent discussion of San Francisco's original linkage program, see Diamond, supra note 6.

63. The San Francisco program is the standard linkage inodel. However, there are many variations. For example, several cities have "incentive-based" programs, under which the developer receives a density "bonus" in exchange for the fee. Soine cities assess the fee not only on office buildings, but on all commercial developinent. Alterman, supra note 56, at 12-17.

64. Porter, supra note 53, at 4.

65. See, e.g., San Francisco Information Clearinghouse, A Critique of San Francisco's Office Housing Production Program With Recommendations for Corrective Action 47 (May 1984).

66. San Francisco, Cal., Planning Code, $\S 313$ (1987) (added by Ordinance 358-85 (July $19,1985)$ ). For an excellent discussion of the specifics of the amended program, see Goetz, supra note 6 , at 66 .

67. Boston, MASS., Zoning CoDE, art. 26 (amended Dec. 29, 1983), supplemented by Boston, MAss., Zoning CoDE, arts. 26A, 26B (adopted Feb. 26, 1986). One part of the 1986 amendinent exacted an additional $\$ 1$ per square foot of floor area over 100,000 square feet for job training. Id. art. 26B, $\S 3(1)(\mathrm{a})$. For a discussion of the Boston program, see Coininent, Opening the Door for Boston's Poor: Will "Linkage" Survive Judicial Review?, 14 B.C. ENVTL. AFF. L. REV. 447 (1987).

68. Porter, supra note 53, at 5.

69. Id. at 5 . The voluntariness of this program is highly questionable. Some couninentators 
program imposes a $\$ 5.00$ per-square-foot $\mathrm{fee}^{70}$ on all office, retail, and institutional developinent over 100,000 square feet regardless of location. ${ }^{71}$

The Boston and San Francisco experiences spurred the enactment of linkage ordinances in a handful of other cities, mcludimg Miami, Seattle, and Hartford, Connecticut. ${ }^{72}$ Linkage has also been proposed or considered in Los Angeles, ${ }^{73}$ Chicago, ${ }^{74}$ Denver, ${ }^{75}$ Washington, D.C., Stamford, Sacramento, Kansas City, ${ }^{76}$ Madison, ${ }^{77}$ and several small California cities. ${ }^{78}$

Because the avowed purpose is to mitigate the negative impact of development on low-income residents, linkage programs have been characterized as mipact fees. Advocates of linkage, however, sometimes speak in redistributive ternis. ${ }^{79}$ Said Mayor Flynn of Boston: “We have a city that is growing and thriving, but ... there are a number of people who are not benefiting from that economic growth. ... We want to see that it's shared with the people in the neighborhoods." "80 Such statements illustrate the blurring of the distinction between fees and taxes.

II

Externalities AND Public Property

\section{A. The Distinction Between Impact Fees and Taxes}

Most regulations promulgated under the police power are justified

suggest that Boston has purposely maintained outdated zoning to preserve its leverage over developers. See, e.g., Susskind \& McMahon, supra note 1, at 211-12.

70. Because the fee is paid in installments (over seven years downtown, and over 12 years in the outlying neighborhoods), the effective charge is substantially lower ( $\$ 3.83$ and $\$ 1.58$ respectively, assuming a $10 \%$ discount rate). See Alterman, supra note 56, at 14. Developers may also build housing rather than pay the fee, but one commentator has noted that developers are more likely simply to write a check. Tegeler, Developer Payments and Downtown Housing Trust Funds, 18 Clearinghouse Rev. 679, 684 (1984).

71. The program also covers residential and industrial construction that directly removes lowincome housing units from the market. Achtenberg, Panel Comments, in INCLusionaRY ZoNING MOVES DownTown 195, 202 (1985).

72. See Porter \& Lassar, supra note 6, at 7 (linkage ordinances have also been enacted in Cambridge, Massachusetts, Jersey City and Prineeton, New Jersey, and Palo Alto and Santa Monica, Califorma). A program approximating linkage has also been enacted in New York City. Alterman, supra note 56, at 17.

73. Interview with Daniel Garcia, partner, Munger, Tolles and Olson, and former president of the Los Angeles City Planning Commission in Los Angeles, (Aug. 25, 1989).

74. Alterman, supra note 56 , at 47 .

75. Comment, supra note 67 , at 447 n.2.

76. Porter \& Lassar, supra note 6, at 7, 11.

77. Alterman, supra note 56 , at 15-16.

78. Porter, supra note 53, at 4.

79. See G. McMahon, L. Susskind, E. Tohn, J. Rustin \& S. Rolley, supra note 6, at 44.

80. Id. (quoting Washington Post, Apr. 12, 1986, at E10, col. 1). 
on the grounds that they eliminate or ameliorate public externalities. ${ }^{81}$ An externality arises when the producer of a good imposes a cost on third parties, which he does not pay-that is, which is "nonpriced."82 In such a case the price system, which normally refiects the preferences of all actors in the economy, ceases to produce an efficient result. ${ }^{83}$ For example, if a farmer lias an absolute right to be free of roaming cattle but the owner of the neighboring ranch nevertheless allows his cows to stray onto the farm and eat the farmer's crops, the rancher imposes an unpriced cost, or externality, on the farmer. ${ }^{84}$

An externality is "public" if it affects a large number of people. For example, when a sweater factory pollutes a stream, it imposes an unpriced cost on all downstream users of the stream. ${ }^{85}$ This externality may be eliminated by imposing a fee on the factory, whicl approximates the costs borne by the downstream users. Such a fee would be a legitimate exercise of the police power.

Taxes, by contrast, are not promulgated under the police power. ${ }^{86}$ They may be imposed on one group simply to benefit the public at large ${ }^{87}$ and need not be linked to a specific liarm flowing from that group's bellavior. ${ }^{88}$

\section{B. Regulating Externalities}

An understanding of externalities is vital in order to grasp the distimction between police power exactions and taxes. Returning to the case of the sweater factory and the stream, the pollution externality has two effects. First, it causes the downstream users to suffer a loss of wealth or "utility." 89 Second, the factory has an imcentive to "overproduce" from society's perspective because the cost of running the factory is higher for society than for the manufacturer. ${ }^{90}$ In other words, if the factory lad to bear the full social costs of production, it would be forced to charge a

81. D. HAGMAN \& J. JUERGENSMEYer, supra note $10, \S 9.8$, at 284.

82. See S. RHOADS, THE Economist's VIEW OF THE WORLD 67 (1985). More precisely, this is a definition of a negative externality. An externality is positive when a third person reaps a benefit from a producer's activities for which the third person does not pay.

83. See id. at 114 ("Real externalities occur when the market's price system breaks down, that is, when it does not take account of some people's preferences.").

84. This classic example is drawn from Coase, The Problem of Social Cost, 3 J.L. \& Econ. 1 (1960).

85. See S. RHOADS, supra note 82 , at 114.

86. 16 E. MCQUILLIN, supra note 48, § 44.05, at 12 .

87. Id. $\S 44.02$, at 6 .

88. See id. $\S 44.05$, at 12 ("Except as restricted by [constitutional] provisions, the power of the state to tax is unlimited.").

89. See S. RHOADS, supra note 82 , at 67 (a negative externality occurs when a cost of a producer's action is imposed on third parties).

90. See id. (because the cost of the externality does not appear on a producer's profit and loss statement, it is usually ignored). 
higher price for sweaters. Hence, society would consume fewer sweaters at the higher price, and the factory would produce fewer of them. With the externality, the cost to society of the excess sweaters is greater than what society would pay for them, and so the society suffers an irrecoverable, or "deadweight" loss. Thus, the externality leads to an inefficient result.

If there were no barriers to negotiation between the factory and the downstream users there would be no externality, because the actors would come to an agreement through which the negative effect would be priced. ${ }^{91}$ The factory would offer a certain sum to the downstream users in exchange for permission to pollute the stream. ${ }^{92}$ The downstream users would either accept the payment and allow the pollution or would refuse it, leaving the factory with the chance to either cease polluting or cease production. ${ }^{93}$

Negotiations to eliminate the externality are easiest and most likely to occur when the externality is "private," particularly when the externality injures only one party, ${ }^{94}$ as in the case of the farmer and the rancher. ${ }^{95}$ In contrast, "public" externalities, such as water pollution, are typically accompamed by substantial barriers to negotiation. Because the affected parties are both numerous and diverse, a bargain is unlikely to be struck ${ }^{96}$ and the producer may be unable to purchase the right to subject the public to some level of negative effects. ${ }^{97}$ Where there is a public externahity like pollution and the third parties have an absolute right to be free of that externality, the affected parties may thus resort to an injunction or regulatory ban to prevent the externahty, forcing the producer to mitigate the effect entirely and underproduce his good from society's viewpoimt.

In order to miprove efficiency, the government may revoke the public's absolute right to be free of pollution. It can then determme the socially optimal level of pollution (that is, estimate what level of pollution would be allowed if bargaining were feasible) and promulgate regu-

91. See W. Fischel, The Economics of Zoning Laws: A Property Rights Approach To AMERICAN LAND USE CONTROLS §6.8.2, at 119 (1985) (for a nuisance to be an externality, there must be some barrier to a contractual agreement between the producer and the third party).

92. This assumes that the downstream users have a legal right to be free of pollution.

93. There is a whole range of intermediate possibilities as well. For example, the downstream users could allow a limited umount of pollution in exchange for a payment, requiring the sweater producer to reduce his production. See Coase, supra note 84, at 3-5.

94. See R. CoOTER \& T. Ulen, LAW \& Economics 170-71 (1988) (when few parties are affected by an externality, bargaining costs are low).

95. See supra note 84 and accompanying text.

96. See R. COOTER \& T. ULEN, supra note 94 , at 171 (bargaining is unlikely to succeed where the cooperation of numerous parties is required).

97. See id. at 175 (when numerous parties are involved in the bargaiming, each has an incentive to be the last to reach an agreement with the producer and thus be in a better bargaining position). 
lations to limit pollution to that level..$^{98}$ If the government chooses properly, the resulting production is efficient froin society's perspective. Of course, this inethod has distributional consequences; the third parties are actually in a worse position than if they had retained the absolute right.

As a third alternative, the government can "price" the pollution by levying a fee on the sweater producer to account for the loss in utility suffered by the third parties. ${ }^{99}$ Depending on the amount of the imposed fee, the producer inay install pollution-reducing devices, reduce production (thus reducing pollution), or stop producing entirely. ${ }^{100}$ The producer thus accounts for the preferences of the third parties in his production and will produce the optimal amount of sweaters with no efficiency loss to society. ${ }^{101}$ Meanwhile, if the fee revenues are distributed to the downstream users, they will be compensated for the loss in utility that they suffer. The downstream users are thus in the same position as if they had an absolute right to prevent pollution, and there are no distributional consequences. ${ }^{102}$

In the land-use arena, government seeks to reduce or prevent the imposition of public externalities flowing froin the "production" of real estate developinents. ${ }^{103}$ For instance, early zoning relegated noxious uses hike factories to certain areas in order to reduce the effects of noise and odor on adjoining residential property. ${ }^{104}$ This type of zoning, grounded in nuisance theory, implied an externality analysis under which residential property owners had a limited right to be free of the factories' negative effects.

Unlike zoning, most inodern-day developinent exaction programs are not simple cases of reducing externalities imposed by developments on adjoining property. Consequently, courts have had difficulty applying externality theory in judging the validity of exactions. Instead, they have

98. See G. Tullock, Private Wants, Public Means 47-49 (1970) (discussing government's role in reducing bargaining costs by establishing regulations which attempt to mirror the private arrangements the parties would have made).

99. These taxes are known by economists as "Pigouvian taxes," after Arthur C. Pigou. See generally A. Pigou, The Economics of Welfare (4th ed. 1938).

100. See G. Tullock, supra note 98 , at 155 (by an appropriate choice of tax, the government may control the amount of pollution).

101. See id.

102. Id. at 74-75 (distributing the "tax" to the third party achieves the optimal result). Although outright regulation of pollution is more commonplace than pricing through taxes, a few courts have "priced" pollution by awarding "permanent dainages" to affected third parties, while allowing the producer to continue producing. See, e.g., Boomer v. Atlantic Cement Co., 26 N.Y.2d 219, 257 N.E.2d 870, 309 N.Y.S.2d 312 (1970).

103. For a discussion of the theoretical underpinnings of land use regulation, see Dunham, supra note 10.

104. See T. SNYDER \& M. STEGMAN, supra note 3, at 5. For an example of early zoning and the Supreme Court's reaction, see Village of Euclid v. Ambler Realty Co., 272 U.S. 365, 388 (1926). 
permitted exactions under the police power and then used complex tests to stem the abuse of this virtually limitless reservoir of authority.

A better approach, however, is to apply externality theory exphicitly and thus simplify the analysis. Indeed, most existing exactions programs do, in fact, accommodate externality analysis. The effects they seek to imitigate may be characterized as either of two types of externalities: (1) intrusions on imphed negative easements benefiting the public, or (2) intrusions on publicly-owned facilities. When the problem is thus framed, externality theory provides the most coherent framework for analyzing the validity of new exactions programs, such as housing linkage fees.

\section{III}

\section{ApPlying EXTernality Theory to IMPACT FeES}

Federal and state courts have differed in their analyses of the validity of developinent exactions. For instance, the Supreme Court has decided that an exaction which does not advance a legitimate state interest that would be impeded by the proposed development violates the takings clause. State courts, ineanwhile, usually require a "nexus" between the exaction and a need created by the development. Many state courts also require that the exaction be used to benefit the development. However, both federal and state approaches to impact fees can be explained as attempts to regulate the externalities of development.

\section{A. Implied Negative Easements}

Most exaction cases fail to reach the federal courts because of the federal judiciary's reluctance to consider challenges to local land-use regulation. A notable exception is the landinark Supreme Court case, Nollan v. California Coastal Commission. ${ }^{105}$ The Nollans sought a permit to construct a larger house on their beachfront property. Claiming that a larger house would block the public's view of the beach from the road, the Coastal Commission conditioned the permit on the Nollans' dedication of an easement for lateral access along the beach. ${ }^{106}$ The Supreine Court held that the required lateral easement amounted to an unconstitutional taking of private property because it did not directly mitigate the public's loss of visual access froin the road. ${ }^{107}$

105. 483 U.S. 825 (1987). For an excellent discussion of Nollan, see Falik \& Shimko, The “Takings" Nexus-The Supreme Court Chooses a New Direction in Land-Use Planning: A View from California, 39 HASTINGS L.J. 359, 376-96 (1988).

106. Nollan, 483 U.S. at 828 . The state argued that construction of the house, "along with other area development, would cumulatively 'burden the public's ability to traverse to and along the shorefront." "Id. at 829 .

107. Id. at 837 . 
The Court first noted that if the government had required dedication of such an easement outside of the development permit process, it would be effectimg a "permanent physical occupation," or per se taking, of the Nollans' property, requiring compensation under the takings clause. ${ }^{108}$ However, the Court found that the state could refuse to issue a development permit if such refusal "substantially advances legitimate state interests." 109 In other words, the Court held that refusal was warranted if the development would "substantially impede" the state's imterest. 110

The Coastal Commission argued that the required easement would advance three state interests: (1) protecting the public's view of the beach, (2) preventing a "psychological" barrier to the use of the beach, and (3) reducing congestion on public beaches. ${ }^{111}$ Without deciding whether these interests were legitimate, the Court noted that the range of legitimate state mterests was broad, mcluding the protection of scenery, historic landmarks, and residential neighborhoods. ${ }^{112}$

The Court reasoned that if the Commission could deny the permit in order to protect state imterests, then it could alternatively grant the permit with conditions designed to serve the same imterests. For example, it could restrict the size or height of the structure to protect the view of the beach, ban the construction of fences, or require the Nollans to dedicate a "viewing spot" to the pubhc. ${ }^{113}$ However, the Court refused to allow a lateral access dedication because it failed to further the state's asserted interests. ${ }^{114}$ In other words, an exaction is permissible under Nollan ouly if it is closely tailored to mitigate an effect of the development on a legitimate state interest. ${ }^{115}$

108. Id. at 831 . While an impact fee is not a physical occupation of property, several commentators note that the language used in the opinion implies that the court could apply its analysis to a variety of land-use regulations. See, e.g., Falik \& Shimko, supra note 105, at 392-96; Note, Municipal Development Exactions, The Rational Nexus Test, and The Federal Constitution, 102 HARV. L. REV. 992, 993 (1989).

109. Nollan, 483 U.S. at 834.

110. Id. at $835-36$.

111. Id. at 835 .

112. Id. at 834-35. For an expansive view of the limits of the police power, see Berman v. Parker, 348 U.S. 26, 33 (1954) (a state may regulate so as to ensure that a community is "beautiful as well as healthy, spacious as well as clean, well-balanced as well as carefully patrolled").

113. Nollan, 483 U.S. at 836.

114. Id. at 837 .

115. Id. at 837. This requirement, which the court calls a "nexus," is widely seen as a departure from established takings and due process analysis. See, e.g., Freilich \& Morgan, Municipal Strategies for Imposing Valid Development Exactions: Responding to Nollan, 10 ZONING \& PLAN. L. REP. 169, 172 (1987) (the Nollan Court ruled that cases that merged the more deferential due process standard with the takings standard were inconsistent with more recent opinions); Note, Taking a Step Back: $A$ Reconsideration of the Takings Test of Nollan v. California Coastal Commission, 102 HaRv. L. REV. 448, 452-54 (1988).

The Court also indicated that one landowner may not be "singled out" to bear a burden disproportionate to other landowners, implying that the exaction must be roughly proportional to 
In a vigorous dissent, Justice Brennan argued that the Court had too narrowly defined the required nexus between the condition imposed and the impeded interest. ${ }^{116}$ However, the majority countered by arguing that a looser nexus would allow cities to "leverage" the police power by producing "stringent land-use regulation which the State then waives to accomplish other purposes." 117 The majority feared that cities might use the police power to take land for public use rather than providing just compensation under the eminent domain power. ${ }^{118}$

Indeed, Nollan reflects the Court's disapproval of the notion that a development permit is a "governmental benefit" for which the landowner may be required to trade his property interests. ${ }^{119}$ Instead, the decision affirms that the landowner may proceed unless the proposed development substantially innedes a legitimate government interest. ${ }^{120}$

Although Nollan dealt with the nritigation of an obvious negative effect (the impingement on the public's visual access to the beach), there must be an infringement of public entitlements or property if the decision is to be reconciled with externality theory. The Court did not explicitly hold that the public had a preexisting riglit to visual access; however, by defining the protection of visual access as a legitinnate interest, the Court implicitly recognized such an entitlement. This entitlement approximates an implied "negative easeinent"-a servitude that restricts the use of private property ${ }^{121}$ - benefiting the public. ${ }^{122}$

The Supreme Court began laying the groundwork for the negative easement concept before it ever decided an exactions case. For example, in Agins v. City of Tiburon, ${ }^{123}$ a zoning change limited the number of

the expected impact of the development. Nollan, 483 U.S. at 835 n.4. This is similar to an equal protection analysis, even though commentators note that since developers are not a suspect class and property development is not a fundamental right, there is no strict scrutiny requirement under the Equal Protection Clause. Alterman, supra note 56, at 33.

116. Nollan, 483 U.S. at $842-43$ (Brennan, J., dissenting).

117. Id. at 837 n.5.

118. Id. at 841 .

119. Id. at 833 n.2.

120. Some commentators have read Nollan narrowly as an application of the "unconstitutional conditions" doctrine, which states that the government cannot condition receipt of a benefit on the applicant's foregoing a constitutional right. See, e.g., Note, supra note 108, at 998; Note, supra note 115 , at 467 . However, given the Court's recognition that the state could properly inpose sone conditions on the landowner, this interpretation is rather suspect. See Nollan, 483 U.S. at 836-37.

121. C. BERGER, supra note 15 , at 532 (the holder of a negative easement receives a benefit that does not contemplate his actual entry onto the grantor's land).

122. In some ways, this view of land-use regulation resembles the "public trust" doctrine, which states that the public retains certain property rights in the land beneath all navigable waters, regardless of whether the state has passed title to such lands to private owners. In California, the courts have applied the doctrine by reading implied conditions, such as a servitude to the public interest, into such grants. See generally Sax, The Public Trust Doctrine in Natural Resource Law: Effective Judicial Intervention, $68 \mathrm{MiCH}$. L. REv. 471 (1970).

123. 447 U.S. 255 (1980). 
houses that the plaintiff could build on his land. The Court stated that the limitation would "substantially advance legitimate government goals," principally the preservation of open space. ${ }^{124}$ This could be interpreted as an imphicit recognition that Agins' land was burdened with a negative easement for public view, and that limitations on development were legal because they mitigated encroachment on that easement. Similarly, in Penn Central Transportation Co. v. City of New York, ${ }^{125} \mathrm{New}$ York City's historic landınarks law effectively burdened all designated buildings with an implied negative easement for public view. The existence of this easement thus justified denying a permit to build an office building atop the Penn Central station. ${ }^{126}$

In Nollan, the Court assuined, without deciding, that a series of public interests in coastal land were "legitimate state interests." 127 However, the Court focused on the protection of the public's view of the ocean froin the road-an interest that presumes a preexisting imiphed negative easement for view across the Nollans' property. Accordingly, the Court was willing to allow a dedication exaction that protected the public's view of the beach-such as a viewing spot on the Nollans' land. ${ }^{128}$ However, it struck down the lateral access exaction as unrelated to the development's impingernent on that entitlement. ${ }^{129}$

Although Nollan is the first Supreme Court exactions case to implicitly recognize an easement benefiting the public, three pre-Nollan beach dedication cases, all from California, made similar findings. The court in each case probably went further than Nollan would allow; nevertheless, these cases are instructive in the various possible applications of the implied easeinent concept.

In Grupe v. California Coastal Commission, ${ }^{130}$ on facts similar to those in Nollan, the court upheld the required dedication of an easement for lateral access across the beach, even though the proposed developinent would not create a "need" for such access. The court dispensed with the "burden" and "benefit" tests recited by most states, ${ }^{131}$ fiatly stating that the usual "nexus" requirement did not apply to beach access exactions "because the objective is different than that in park, street, and

124. Id. at 261 .

125. 438 U.S. 104 (1978).

126. Id. at 116-17.

127. 483 U.S. at 835 . The Court never reached the question of whether the interests asserted by the state were legitinate. Id. at 836 . However, given the historically broad construction of the police power, it is unlikely that the Court would take issue with the interests recited by the state in this case. See supra note 112 and accoinpanying text.

128. Nollan, 483 U.S. at 836.

129. Id. at $837,841-42$.

130. 166 Cal. App. 3d 148, 212 Cal. Rptr. 578 (1985).

131. See infra text accompanying notes 148-57. 
sewer exactions." ${ }^{132}$ This implies a recognition that oceanfront development encroaches on a series of public property rights, such as those asserted in Nollan, and that the government may require dedication of a lateral access easement in exchange for permission to allow such encroachment.

The state in Georgia-Pacific Corp. v. California Coastal Commission ${ }^{133}$ required dedication of a vertical access easement (from the road to the beach), as well as a series of lateral easements, even though the proposed development would not have interfered with access. The court upheld the vertical easement and one of the lateral easements on the grounds that the dedications served the "general welfare."134 Like the Grupe court, this court dispensed with the requirement that the development create a "need" for the required dedication. ${ }^{135}$ Thus it, too, implicitly recognized an encroachment on a series of public entitlements, and allowed for "compensation" of the public's loss through the dedication of express public easements for vertical and lateral access.

In contrast, a federal district court in Sea Ranch Association v. California Coastal Commission ${ }^{136}$ justified the dedication to the public of a vertical easement for physical access by implying that the public already had an implied vertical easement. The court said that the development would increase the "existing need" for public access to state beaclies, ${ }^{137}$ and that the state was justified in requiring the developer to satisfy that need by expressly dedicating a vertical easeinent. ${ }^{138}$

The dedications required in Grupe and Georgia-Pacific probably do not pass the Nollan test, since the required dedication in each failed to directly mitigate the stated encroachments. Meanwhile, the Sea Ranch court's creation of an implied easement for physical access, because it amounts to an affirmative ${ }^{139}$ rather than negative easement, probably fails under Nollan. The Court in Nollan suggested in dicta that there is no public riglit to enter onto private land to get to navigable tidewaters, ${ }^{140}$ emphasizing that " "the riglit to exclude others is one of the most essential sticks in the bundle of rights that are commonly characterized as property." "141 Thus, while Nollan enables states to burden private

\footnotetext{
132. Grupe, 166 Cal. App. 3d at 165, 167 n.13, 212 Cal. Rptr. at 588, 590 n.13.

133. 132 Cal. App. 3d 678, 183 Cal. Rptr. 395 (1982).

134. Id. at 699,183 Cal. Rptr. at 407.

135. Id., 183 Cal. Rptr. at 407.

136. 527 F. Supp. 390 (N.D. Cal.), vacated and remanded on other grounds, 454 U.S. 1070 (1981).

137. Id. at 395 .

138. Id.

139. See C. BERGER, supra note 15 , at 531 (an affirmative easement privileges the holder to enter and use the grantor's land, and bars the grantor from interfering with that use).

140. 483 U.S. at 833 .

141. Id. at 831 (quoting Loretto v. Teleprompter Manhattan CATV Corp., 458 U.S. 419, 433
} 
property with implied negative easements, the affirmative easements created by the Sea Ranch court would seem impermissible.

\section{B. Publicly-Owned Facilities: State Cases}

State exaction doctrine is a patchwork of conflicting decisions. This is partly attributable to the fact that state courts rarely apply a federal "takings" analysis, instead relying on state constitutional and statutory provisions as well as widely divergent notions of property riglits. ${ }^{142}$

In most cases, state courts are concerned with pohicing the constitutional boundary between a municipality's power to regulate and its power to tax: ${ }^{143}$ whether the exaction is a "regulatory fee" imposed under the state's grant of general police power to a municipality ${ }^{144}$ or a tax imposed under the requisite specific statutory autliority. ${ }^{145}$ Because specific statutory authority for a tax is invariably lacking in exactions cases, the finding that an exaction is a tax leads to invalidation by the court.

Although generalizations about the various state doctrines are difficult to make, a four-part test is identifiable:

First, lias the state authorized the locality to require a dedication or impact fee through its zoning, utility or subdivision enabling acts, ${ }^{146}$ or

(1982)). However, the Nollan court indicated that the public could obtain physical easements across private land by prescription. Id. at 833 . In this vein, it is worth considering that the Georgia-Pacific court bolstered its argument by noting that the vertical easement required by the state coincided with a route alrcady used by the public for access to the coast. Georgia-Pacific, $132 \mathrm{Cal}$. App. 3d at 699, 183 Cal. Rptr. at 408. Compare Liberty v. California Coastal Comin'n, 113 Cal. App. 3d 491, $500,170 \mathrm{Cal}$. Rptr. 247, 253 (1980) (court hypothesized that all of the California "beach case" decisions may reflect some notion of a public prescriptive easement).

142. See Note, supra note 108 , at $995-96$ (citing numerous state cases applymg the same rational nexus test but for three distimct purposes).

143. Id. at 995.

144. See 6A E. MCQuILLIN, supra note 48, $\$$ 24.43-.44 (3d rev. ed. 1988) (describimg the broad scope of this grant). The notion of the proper purpose of a regulatory fee has evolved rapidly to accommodate the rise of exactions. As late as 1980, the Califorina courts limited the use of such fees to paying the administrative costs associated with regulation. Mills v. County of Trinity, $108 \mathrm{Cal}$. App. 3d 656, 166 Cal. Rptr. 674 (1980); see also United Business Comm'n v. City of San Diego, 91 Cal. App. 3d 156, 165-66, 154 Cal. Rptr. 263, 269 (1979). However, later decisions expanded the coverage of regulatory fees to services required by the regulated activity, such as infrastructure made necessary by real estate development. See, e.g., Russ Bldg. Partnership v. City \& County of San Francisco, $199 \mathrm{Cal}$. App. 3d 1496, 1506, $246 \mathrm{Cal}$. Rptr. 21, 26 (1987) (upholding the imposition of a fee intended to compensate for an increased need for public transit resulting from an office development). A "user fee," meanwhile, is distinguishable from a regulatory fee; it is more aptly defined as a "rent" for a goverument service or facility. See M. GelFand \& P. SALSICH, State AND Local TAXation AND FinANCE IN A NuTSHELl 91 (1985). For one statutory definition of user fees, see CAL. Gov'T CoDE $\S 50076$ (West 1983).

145. 16 E. MCQUILLIN, supra note $48, \S 44.05$, at 12 .

146. See, e.g., Jordan v. Village of Menomonee Falls, 28 Wis. $2 d 608,615,137$ N.W.2d 442, 446 (1965), appeal dismissed, 385 U.S. 4 (1966). 
other specific legislation? ${ }^{147}$

Second, is there a demonstrable connection between the exaction and the "needs" or "burdens" created by the development? Most courts require a "rational nexus" between the two; ${ }^{148}$ however, Illinois courts apply a somewhat stricter test, requiring that the exaction fulfill needs " 'specifically and uniquely attributable" to the development in question, ${ }^{149}$ while California courts use a more relaxed standard, requiring only a "reasonable relationship" between the needs and the exaction. ${ }^{150}$ (As noted earlier, California courts have dispensed with any showing of need in cases involving dedications for public beach access. ${ }^{151}$ )

Third, will the exaction be spent to benefit the developnient? One state court held that exactions should be evaluated under the same standard as special assessments; that is, that the amount of the exaction inay not substantially exceed the benefits accrumg to the subdivision from the facility. ${ }^{152}$ California courts, on the other hand, though requiring some showing of benefit, have upheld exactions when the general public also benefitted from the funded facility ${ }^{153}$ and have indicated that they night uphold an exaction when the facility was some distance front the development. ${ }^{154}$ Further, im the "beach access" cases, the California courts

147. See, e.g., Pioneer Trust \& Savings Bank v. Village of Mount Prospect, 22 Ill. 2d 375, 380, 176 N.E.2d 799, 802 (1961).

148. See, e.g., Wald Corp. v. Metropolitan Dade County, 338 So. 2d 863, 867-68 (Fla. App. 1976), cert. denied, 348 So. $2 d 955$ (Fla. 1977). A Wisconsin case is commonly cited for this test, even though the court there never used the phrase "rational nexus." See Jordan v. Village of Menomonee Falls, 28 Wis. 2d 608, 137 N.W.2d 442 (1965), appeal dismissed, 385 U.S. 4 (1966).

149. Pioneer Trust \& Savings Bank, 22 111. 2d at 379, 176 N.E.2d at 801 (quoting Rosen v. Village of Downers Grove, 19 Ill. 2d 448, 453, 167 N.E.2d 230, 233 (1960)). Although this decision was once interpreted to mean that only facilities used solely by the development were valid subjects of a fee, later Illinois deeisions allowed cities to apportion the need for a facility among multiple developments. See Krughoff v. City of Naperville, 68 Ill. 2d 352, 358-59, 369 N.E.2d 892, 895 (1977); Board of Educ. v. Surety Developers, Inc., 63 Ill. 2d 193, 203-04, 347 N.E.2d 149, 154 (1975).

150. Associated Homebuilders v. City of Walnut Creek, 4 Cal. 3d 633, 645, 484 P.2d 606, 61516, 94 Cal. Rptr. 630, 639-40 (1971), appeal dismissed, 404 U.S. 878 (1972). The Supreme Court in Nollan may have invalidated the California test, in noting that its analysis was consistent with all state tests but California's. See Nollan v. California Coastal Comm'n, 483 U.S. 825, 839-40 (1987).

151. See supra notes $130-35$ and accompanying text.

152. See Land/Vest Properties, Inc. v. Town of Plainfield, 117 N.H. 817, 823, 379 A.2d 200, 204 (1977). However, this reasoning taken literally would virtually preclude the usc of fees for anything but on-site facilities, since a developer normally derives only a marginal benefit from the construction of off-site facilities. See infra note 190.

153. See Ayres v. City Council of Los Angeles, 34 Cal. 2d 31, 41, 207 P.2d 1, 7 (1949) (it is no defense to conditions imposed in a subdivision map proceeding that their fulfilment will also benefit the city as a whole).

154. See Associated Homebuilders, 4 Cal. 3d at 640 n.6, 484 P.2d at 612 n.6, 94 Cal. Rptr. at 636 n. 6 (in light of the need for reereational facilities and the increasing mobility of the population, an inlieu fee might properly be used to purchase land some distance from the development). 
simply defined the benefit as the state's granting of the permit. ${ }^{155}$ To avoid this slippery slope, several other states require the municipality to use exactions proceeds for their stated purpose. For example, Florida inandates that impact fee funds be earmarked, ${ }^{156}$ while Washington requires that the fees be refunded to the developer if not spent for their stated purpose within a certain time period. ${ }^{157}$

Fourtl, since new residents should not subsidize existing residents, is the fee proportional to the needs created by the development? New Hampshire and Utah liave been particularly vigilant im this regard, applying complex cost-accounting methods to determine whether the fee approximates the burden created by the development. ${ }^{158}$

In an effort to control the use of impact fees, a number of states liave passed impact fee statutes. In addition to defining the proper objects of a fee, these statutes establish the test for a valid impact fee. California, for example, requires a city to establish reasonable relationships between (1) the type of development and the need for the facility (burden), (2) the type of development and the use of the fee (benefit), and (3) the amount of the fee and the cost of the portion of the facility attributable to the development (proportionality). Further, the statute requires that funds be earmarked for the stated facility and refunded if not spent within five years. ${ }^{159}$

The state courts, dealing largely with exactions for public facilities, have used various formulations of the four part test, but have never explicitly applied externality theory. The second part, and core, of the test would accommodate externality theory but for the fact that the state courts, like the Supreine Court in Nollan, refuse to identify explicitly the public entitleunent or property on which the proposed developinent would encroach.

155. See, e.g., Grnpe v. California Coastal Comm'n, 166 Cal. App. 3d 148, 176-77, 212 Cal. Rptr. 578, 596-97 (1985).

156. See, e.g., Contractors \& Builders Ass'n of Pinellas County v. City of Dunedin, 329 So. $2 d$ 314, 321 (Fla. 1976); Hollywood, Inc. v. Broward County, 431 So. 2d 606, 611-12 (Fla. Dist. Ct. App.), petition denied, 440 So. 2d 352 (Fla. 1983).

157. See, e.g., Miller v. City of Port Angeles, 38 Wash. App. 904, 911-12, 691 P.2d 229, 234-35 (1984), review denied, 103 Wash. 2d 1024 (1985).

158. See, e.g., Land/Vest Properties, Inc., 117 N.H. at 820-24, 379 A.2d at 203-05; Lafferty v. Payson City, 642 P.2d 376, 379 (Utah 1982); Banberry Dev. Corp. v. South Jordan City, 631 P.2d 899, 903 (Utah 1981).

159. CAL. Gov'T CODE $\$ \S 66000-66001$ (West Supp. 1990); see also ARIz. Rev. STAT. ANN. $\S 9-463.05$ (West 1990) (inposing benefit, burden, and earmarking requirements); WASH REv. CODE ANN. $\S 82.02 .020$ (Supp. 1990) (imposing burden and earmarking requirements). For advisory literature on drafting a legally defensible local impact fee ordinance, see Leitner \& Strauss, Elements of a Municipal Impact Fee Ordinance, with Commentary, 54 J. AM. PLAN. A. 225 (1988); Morgan, Duncan \& McClendon, Drafting Impact Fee Ordinances: Legal Foundations for Exactions, 9 Zoning \& PLAN. L. Rep. 49 (1986); Stewart, So You Want to Prepare a Development Impact Fee Ordinance, 54 J. AM. Plan. A. 71 (1988). 
However, it is possible to bridge this gap by recognizing the inplicit finding by these courts that the existing public facilities used by the tenants of a new developinent, such as roads, parks, and utilities, are the "property" of existing residents, and that these existing residents are thus subject to externalities relating to the new tenants' use.

To understand why an externahity exists in this context, we must distinguish between "private" and "public" goods. In a capitalist economy, the goods and services provided by governinent are those that cannot properly be supphied through the free market. In distinguishing goods that can be provided privately from goods requiring collective action, economists classify them according to two characteristics: (1) the ability of the provider of the good to exclude potential users unless they meet the conditions he sets (exclusion), ${ }^{160}$ and (2) the extent to which the good can be consumed jomtly and simultaneously by multiple users without being diminished in quahity or quantity (joint consumption). ${ }^{161}$

Goods having strong exclusionary properties and incapable of joint consumption, such as food and housing, are known as "private" goods, and are typically provided through the free market. ${ }^{162}$ The price of a private good acts as a perfect "user fee," thus encouraging the optimal level of consuinption.

Goods lacking exclusionary properties and capable of joint consumption are "public" goods. ${ }^{163}$ National defense and highways are examples of public goods. ${ }^{164}$ Since one carmot exclude nonpayers from consuming a public good, ${ }^{165}$ the provider of such a good suffers from the so-called "free rider problem," as some or all consumers of the good consume it without paying. ${ }^{166}$ Since the provider of a public good cannot recoup a profit, there is no incentive for anyone to produce public goods and the private inarket will not produce an optinal anount of these goods. ${ }^{167}$ Instead, government must provide such goods and coerce the

160. E. Savas, Privatizing the Public Sector 30 (1982).

161. Id. at 31 .

162. Id. at 38.

163. Id. at 42. There are two other classes of goods: those that lack exclusionary properties and cannot be jointly consumed (such as depletable natural resources), known as "common-pool" goods, and those that have strong exclusionary properties and can be jointly consumed (such as cable television and sewerage), known as "toll" goods. Id. at 39-42. Neither type of good is relevant to this analysis.

164. Id. at 42. Actually, none of these are pure public goods. Each has some exclusive properties. For example, the government has been able to charge user fees in national parks and tolls on highways. For a discussion advocating the application of user fees to more government-provided goods, see Netzer, Exactions in the Public Finance Context, 10 N.Y. AFF. 35, 44-45 (1988).

165. See D. HaGman \& J. JUERGENSMEYer, supra note 10, at 284 (noting the difficulty in preventing nonpayers from benefiting from capital improvements to roads and parks).

166. E. SAVAS, supra note 160 , at 42.

167. Id. 
public into paying for thein, usually by imposing general taxes. ${ }^{168}$

Most forms of public infrastructure, such as roads and parks, have strong public-good qualities. They are consuned by multiple users without diminishing their quality or quantity. Further, it is difficult to exclude nonpayers. As a result, public infrastructure must be (and typically is) funded by the residents of the area through taxes. In a sense, then, this infrastructure is "owned" by those residents.

When new residents move into the area, they use the existing public infrastructure without having paid for it - the classic free rider problein. Ideally, the taxes paid by the new residents would pay for their slare of the cost of existing infrastructure. ${ }^{169}$ However, because of constraints on taxation powers, many commurities are unable to use taxes to mipose the full average cost of such infrastructure on new residents.

Of course, if public infrastructure were a "pure" public good-that is, if joint consumption even at high levels did not diminisls its quality or quantity-then the new users could be accommodated at no cost and witl no negative effects on existing users. However, roads, parks, and other forms of infrastructure actually lose their joint-consuinption properties at some threshold of use and become congested. They are thus more aptly called "congestible public goods."170 Many public facilities im rapidly growing areas-inost notably roads-are subject to this phenoinenon.

If the existing residents "own" the existing facilities, then they can be said to be entitled to zero congestion of those facilities. ${ }^{171}$ Thus when new residents cause congestion, they impose a cost on the existing residents. ${ }^{172}$ To the extent that property taxes paid by the new residents are not sufficient to fund the necessary expansion of public facilities, the existing residents suffer an externality. ${ }^{173}$ Under this analysis, the

168. Id. Government provision of public goods through general tax revenue eliminates the free rider probleın; however, since an individual user's tax does not vary with consumption, there remains a tendency toward overconsumption of such goods. See T. SNYDER \& M. STEGMAN, supra note 3 , at 30 .

169. Blewett and Nelson have likened communities to "clubs." New residents inust "buy" their way into these clubs by paying for their fair share of infrastructure. See Blewett \& Nelson, $A$ Public Choice and Efficiency Argument for Development Impact Fees, in DEVELOPMENT ExACTIONS, supra note 2, at 281, 285.

170. See Rubinfeld, The Economics of the Public Sector, in 2 HANDBOoK OF PUBL1C EcoNomICs 571, 580 (1987) (discussing the economic effects of congestion of public goods).

171. See Fischel, The Economics of Land Use Exactions: A Property Rights Analysis, 50 LAW \& CONTEMP. PROBS. 101, 110 (Winter 1987) (arguing that members of the existing community, out of fairness, are entitled to "zero congestion").

172. See D. HAGMAN \& J. JUERgEnSmeyer, supra note 10 , at 285 (for example, if a new development causes overcrowding in a public park, a social cost is created).

173. A new resident, like an old resident, is inconvenienced by congestion, but the "cost" he bears as a result does not approxinate the full burden he imposes on all other users of the facility. See G. TULLOCK, supra note 98 , at 80 (the cost inflicted on other users may be substantially greater 
mumcipality is justified in usmg the police power to exact dedications and impact fees to mitigate the externality mherent in congestion of pubhic facilities.

\section{IV}

\section{ELIMINATING THE EXTERNALITY}

Externality theory provides a sound analytic framework for analyzing the validity of impact fees. It cannot, however, prevent municipalities from abusing the power to define externalities. Indeed, a municipality reinains free to identify a spurious state interest, clain an encroachment on that interest, and extort a payment from the developer. Alternatively, the murnicipality may overstate the cost of initigating a valid externality, leading to an excessive payment. This Part examines how the Nollan Court's "rational nexus" test and the state courts' "benefit" test atteinpt to address this problein.

Regardless of whether it mvolves an inphed public easement or a public facility, the externality imposed on existing residents by new developinent has two effects: (1) it reduces the wealth of the existing residents (the distributional effect), and (2) it gives the developer an incentive to develop more extensively than he would if the externality were "priced," resulting in overproduction (tlie efficiency effect). ${ }^{174}$

In order to ehminate the externahity, a state has four clioices. First, it could deny the development permit outright, as the city did in Penn Central. ${ }^{175}$

Second, it could grant the permit, but limit the scope of the develop-

than the cost suffered by the new user). Thus, his ability to enjoy the use of the facility at reduced cost is seen as a benefit. This benefit is passed in the form of higher rents on to the developer of the projeet and then back to the landowner as increased land value. Landowners thus receive a "windfall" from the existence of prepaid infrastructure near their land. In an often-quoted treatise on land-value capture, this increment has been called "Windfall II." Jacobsen \& McHenry, Exactions on Development Permission, in WINDFAlls for W1PEOUTS: LAND VALUE CAPTURE AND Compensation 342, 364 (1978).

174. Underpriced road systeins coinmonly result in phenomena such as "suburban sprawl" and a "jobs/housing imbalance." Because neither developers nor their tenants pay the true cost of road usage, residential development becomes widely dispersed and excessively distant froin work centers. See generally Blewett \& Nelson, supra note 169.

175. See Penn Cent. Transp. Co. v. City of New York, 438 U.S. 104, 117 (1978). The courts in public facilities exactions eases typically do not discuss the state's ultimate right to refuse development permission entirely in order to alleviate the burden on public facilities. However, an earlier line of cases upholding growth moratoria established that a city does retain this right, provided it makes a good-faith effort to construct the necessary facilities over time. See Associated Homebuilders v. City of Livermore, 18 Cal. 3d 582, 557 P.2d 473, 135 Cal. Rptr. 41 (1976) (upholding denial of permits based on congestion of schools and sewer systems); Golden v. Planning Bd. of Town of Ramapo, 30 N.Y.2d 359, 285 N.E.2d 291, 334 N.Y.S.2d 138, appeal dismissed, 409 U.S. 1003 (1972). 
ment. The zoning scheme reviewed in Agins accomplished this. ${ }^{176}$

Third, it could grant the permit, but require an exaction directly mitigating the encroachment. Most facilities exactions upheld by the state courts, as well as the "viewing spot" proposed by the court in Nollan, ${ }^{177}$ fit into this category.

Fourth, the state could grant the permit, but impose an exaction that would "coinpensate" the public for the loss suffered as a result of the encroachment. The lateral easeinent dedication struck down in Nollan ${ }^{178}$ and the beach dedications upheld in Georgia-Pacific ${ }^{179}$ and Grupe $^{180}$ fit into this category.

Option 1, outright denial of the permit, ensures that existing residents will not suffer a loss of wealth due to third-party effects. However, denial of the permit is efficient only when the public places a higher value on being free froin the effects than the developer is willing to pay for permission to impose thein. In such a case, even if bargaining were possible, the developer would be unable to entice the public to accept any level of third-party effects and no bargain would be struck. The optimal level of the third-party effects is thus zero and denying the permit leads to an efficient result. However, when the public is ainenable to accepting a money payinent froin the developer as coinpensation for enduring soine level of third-party effects, then outright denial leads to the underproduction of developnient and an efficiency loss to society.

Alternatively, Options 2 and 3 involve the government estimating the optimal level of the third-party effects (that is, what the developer and the public would have agreed to if bargaining were possible). The government then requires the developer either to mitigate the effects accordingly by scaling down the project (Option 2), or to pay an exaction whose proceeds are earmarked for mitigation (Option 3). ${ }^{181}$ Both

176. Agins v. City of Tiburon, 447 U.S. 255, 257 (1980) (the zoning scheme limited development by allowing only single-family dwellings and accessory buildings).

177. Nollan v. California Coastal Comm'n, 483 U.S. 825, 836 (1987).

178. Id. at $837-42$. The Court determined that the lateral access easement would not directly mitigate the burden (reduction of visual access to the beach) imposed by the development. Id. at 837.

179. Georgia-Pacific Corp. v. California Coastal Comm'n, 132 Cal. App. 3d 678, 686-87, 183 Cal. Rptr. 395, 399-400 (1982).

180. Grupe v. California Coastal Comm'n, $166 \mathrm{Cal}$. App. 3d at 148, 156, 212 Cal. Rptr. 578, 581 (1985).

181. This assumes that impact fees and dedications are imperfect mitigation measures and can thus reduce, but not totally eliminate, third-party effects. If complete mitigation were possible through an exaction program, the courts would probably require cities to institute such programs rather than denying permits outright. See Associated Homebuilders v. City of Livernore, $18 \mathrm{Cal} .3 \mathrm{~d}$ 582, 608, 557 P.2d 473, 488, 135 Cal. Rptr. 41, 56 (1976) (implying that a permanent ban on construction imight be "unreasonable"); Golden v. Planning Bd. of Town of Ramapo, 30 N.Y.2d 359, 380, 285 N.E.2d 291, 303, 334 N.Y.S.2d 138, 153-54, appealed dismissed, 409 U.S. 1003 (1972) (sinilar reasoning). 
methods have distributional consequences. Since the optimal level of third-party effects is presumably greater than zero, there is incomplete mitigation of those effects and the public is worse off than if the permit had been demied outright. Further, there may be efficiency consequences: If the government chooses the wrong combination of mitigation and third-party effects, there will be an over- or underproduction of mitigation, with the attendant effects on efficiency.

Option 4 is the better response since it is an exaction designed not to eliminate the third-party effects, but to compensate the public for the loss of utility suffered as a result of such effects. The public, through its local government, is then free to spend as much of the proceeds as it desires to mitigate the effects. ${ }^{182}$ Since the public is fully compensated, it is as well off as it would be with denial of the permit. And, since the private cost to the developer accurately reflects the social cost of developinent, there is an efficient amount of development and no efficiency loss to society. ${ }^{183}$

Although a conipensatory exaction scheme is the option that consistently eliminates both the distributional and efficiency consequences of new development, the Suprene Court and most state courts have resisted such schemes. They have instead permitted exactions only under Option 3 , with the proceeds earmarked for mitigation of the perceived effect on the public facility or easement. ${ }^{184}$

The reluctance of courts to embrace conpensatory exactions is rooted in the fear that mumicipalities will be tempted to use such exactions to extort the increniental increase in value resulting from development approval. ${ }^{185}$ Indeed, given that some California courts have flatly stated that developnient approval is a privilege ${ }^{186}$ or benefit ${ }^{187}$ for which the landowner nray be required to exchange something, ${ }^{188}$ the fear that

182. For a discussion favoring this method, see Fischel, supra note 171.

183. In the case of a public facilities exaction, some inefficiency would remain because of the nature of public goods. An exaction, unlike a tax, does not vary with the level of consumption, and so is not an ideal "user fee." Downing \& McCaleb, Economics of Development Exactions, in Development EXACTIONS, supra note 2, at 42, 52.

184. See supra notes 108-15 \& 152-57 and accompanying text.

185. This increment is dubbed "Windfall I" by Jacobsen \& McHenry. It is to be distinguished from "Wimdfall II," the increment resulting from the installation of prepaid infrastructure near the landowner's property. See Jacobsen \& McHenry, supra note 173, at 364. Impact fees have traditionally been used to appropriate Windfall II, but not Windfall I. Jacobsen \& Redding, Impact Taxcs, in Windfalls for Wipeouts: LAND VAlue CapTURE and Compensation 367, 368 (1978) (using the phrase "inpact taxes" to describe what this Comment refers to as "impact fees").

186. See, e.g., Terminal Plaza Corp. v. City \& County of San Francisco, 177 Cal. App. 3d 892, 907, 223 Cal. Rptr. 379, 387 (1986); Trent-Meredith, Inc. v. City of Oxnard, 114 Cal. App. 3d 317, 325, 170 Cal. Rptr. 685, 689 (1981) (quoting J. LoNGtin, CaliforNIA LAND USE REgulations 617 (1977)).

187. See, e.g. Associated Homebuilders v. City of Walnut Creek, 4 Cal. 3d 633, 644, 484 P.2d 606, 615, 94 Cal. Rptr. 630, 639 (1971), appeal dismissed, 404 U.S. 878 (1972); Grupe v. California Coastal Comm'n, 166 Cal. App. 3d 148, 176, 212 Cal. Rptr. 578, 596 (1985).

188. In his seminal article on subdivision exactions, Professor Johnston argues that the 
cities would use compensatory exactions in order to "sell" development permits is a valid one. The Nollan Court expressed concerns that, with the virtually unbridled discretion that cities possess both to define "legitimate public interests" and to protect those interests through police power regulations, compensatory dedication schemes could lead to "outand-out extortion." As the Court stated,

One would expect that a regime in which this kind of leveraging of the pohice power is allowed would produce stringent land-use regulation which the State then waives to accoinphish other purposes, leading to lesser realization of the land-use goals purportedly sought to be served than would result from more lement (but non-tradeable) development restrictions. ${ }^{189}$

By strictly limiting the use of impact fees and dedications to direct mitigation of effects on the asserted state interest, the Nollan Court somewhat compromised efficiency in order to discourage cities from using the pohice power to capture development approval value. Similarly, the "benefit" test apphied by the state courts in public facilities cases effectively requires direct mitigation of the externality ratler than compensatory payments to the public. ${ }^{190}$

Both the state and federal tests are intended to ensure that fees and dedications are used only for direct mitigation of effects on important state interests. They also address the risk that under a compensatory fee system a city conld overstate the extent of a negative effect, and thus gain excessive compensation. ${ }^{191}$ Theoretically, permitting agencies are thereby prohibited from creatimg spurious state interests or overestimating impacts as a pretext for compensation. ${ }^{192}$ As the following discussion demonstrates, however, the courts also must examine whether the negative effect identified by the municipahty to justify the exaction is, in fact, a true externality.

"privilege" rationale for exactions, and its corollary, that development is a "voluntary act," rest on shaky ground. See Johnston, Constitutionality of Subdivision Control Exactions: The Quest for a Rationale, 52 CORNELI L. Q. 871 (1967).

189. Nollan, 483 U.S. at 837 n.5.

190. In fact, most courts do not actually apply a strict benefit test to exactions. When taken to its logical conclusion, the test requires that the benefit accruing to the development from the funded facility equal or exceed the amount of the fee. However, a development will normally benefit only marginally from the construction of new off-site facilities, such as roads, since its residents or tenants can easily piggyback onto existing facilities. Thus, a strict application of benefit analysis should logically obviate the use of exactions to fund anything but on-site infrastructure-such as roads and sewerage within the development. The commentators, in attempting to explain the use of the benefit test to support exactions for off-site infrastructure, perpetuate the confusion. See, e.g., Netzer, supra note 164, at 44 (likening exactions to "user fees"); Alterman, supra note 56, at 31 (asserting that developinents are "dependent" on impact fees to fund the infrastructure they use).

191. Indeed, the compeusation that a mumcipality could require under a compensatory scheme is limited only by the increased value of the property resulting from development approval.

192. But cf. Note, supra note 115 , at 455-65 (favoring greater deferencc to the legislature's assessments of costs and benefits). 


\section{LiNKAgE: Mitigating the NoN-Externality}

The mitigation requirement embodied in the state and federal tests provides some rudimentary protection against municipalities creating or overestimating negative effects in order to capture development value from landowners. However, neither test effectively forecloses the use of exactions to mitigate negative effects that do not qualify as externalities. Housing linkage fees highlight this gap in existing exaction doctrine.

While a linkage program has never been tested in court, ${ }^{193}$ one 1might pass muster under Nollan if the preservation of low-incoine private housing is defined as a legitimate state interest and if the fee sufficiently advances that interest. Similarly, a linkage program would probably satisfy the "burden" test apphed by most state courts. However, because the proceeds of a linkage fee rarely, if ever, subsidize the housing occupied by new office workers, many state courts would likely hold that the requisite "benefit" does not exist. ${ }^{194}$ This Part takes a different approach and argues that linkage programs should be struck down because they do not mitigate externalities, but instead merely compensate other members of the public for negative "price effects."

The externality that linkage fees purportedly mitigate is best described by a 1984 economic study coinmissioned by the San Francisco Department of City Planning: ${ }^{195}$

1. Additional workers in new office buildings ${ }^{196}$ increase deinand for housing, thus temporarily increasing the market price of housing (rent).

2. The supply of new housing imcreases to the extent that the increased market price justifies building new housing.

3. The new workers with the highest incomes move into the inore expensive new units.

4. The new workers unable to afford the new housing compete

193. One Massachusetts trial court held a housing "linkage" program to be illegal, but the decision was later overturned on procedural grounds. See Bonan v. General Hosp. Corp., 398 Mass. 315, 316-17, 496 N.E.2d 640, 641-42 (1986) (reversing trial court's decision without reaching the merits). Much of the hiterature concerning linkage cites Russ Building Partnership v. City and County of San Francisco, 199 Cal. App. 3d 1496, 246 Cal. Rptr. 21 (1987), as a "linkage" case, but the fee in that case is more aptly described as an inpact fee for public transit services.

194. Indeed, the benefit test applied by some state courts could provide limited protection, but it is rarely construed strictly and so is a poor deterrent. See supra note 190.

195. Recht, Hausrath \& Assocs., supra note 9.

196. Although linkage fee programs imply that office buildings "create" office employment, one economist has pointed out that office buildings "do not create office employment any more than cribs make babies." Instead, he asserts that employment growth creates the need for office buildings. Gruen, The Economics of Requiring Office-Space Development to Contribute to the Production and/or Rehabilitation of Housing, in Downtown LinKages 34, 36 (D. Porter ed. 1985). 
with existing renters for a fixed supply of existing housing, causing rents for existing units to increase.

5. Existing renters then either (1) pay more rent, (2) increase occupancy levels, or (3) vacate and nove elsewhere. ${ }^{197}$

6. New workers move into the vacated existing units. ${ }^{198}$

The study estimated that the total deinand for in-city housing produced by workers in a one million square-foot office building would be 386 units. ${ }^{199}$ It found that while soine of the needed units would be supplied by new construction affordable to higher-nicoine office workers, many units would be supplied from existing housing stock, through the displacement process. ${ }^{200}$

To prevent displacement of existing tenants, the study proposed subsidizing construction of enough new units so that workers would not have to conipete for existing units. ${ }^{201}$ The study divided the office workers into incoine strata and determined the subsidy necessary to make new units "affordable"202 to the workers in each stratum. Adding all of the necessary subsidies, the study calculated the total subsidy aniount required for a one million square-foot office building. Then it divided the total subsidy by one million, yielding a proposed fee of between $\$ 9.47$ and $\$ 10.47$ per square foot. ${ }^{203}$

If these figures are correct, a linkage fee in the \$10-per-square-foot range, if spent to subsidize new units as the study describes, would effectively stem the rent increases correlated with new office developinent. Thus, such a fee would help to preserve the wealth of existing residents much like any other exaction. ${ }^{204}$

Indeed, the San Francisco study clearly shows how new office developinent inposes a negative effect on existing renters-an effect which may appear at first to be an externality. However, it is impossible to classify the negative effect addressed by linkage programs under either the "publicly-owned facilities" or "implied negative easements" rubric.

197. The study asserts that low-incone reuters are least able to pay more for their units, and so will likely increase occupancy or vacate. Recht, Hausrath \& Assocs., supra note 9, at 3.

198. Id. at 2-3.

199. Id. at 11 .

200. Id. at 2-3.

201. Id. at 12-14.

202. The study defined "affordable" rental units as those renting for $30 \%$ of household income. A similar formula was used for purchased units. Id. at 13.

203. Id. at 14.

204. See supra note 101 and accompanying text. Although San Francisco has collected its fees on the basis of these estimated subsidies, the proceeds have not been earmarked specifically to benefit new office workers, or even persons in the incone strata identified by the study; instead, they are deposited in a trust fund, which is used simply to subsidize "low- and middle-incone housing." In fact, some of these funds have been used to provide subsidies to senior citizens whose wage income is presumably close to zero. See A. MallaCh, supra note 56, at 172. 
First, linkage fees are not a public facilities exaction. Although some lousing is provided or subsidized by the federal government, the vast majority is supplied by the private inarket. ${ }^{205}$ This is no accident; lousing, because it is highly exclusive and mdividually consumed, is the quintessential private good. ${ }^{206}$ Unlike the consumer of a road or a park, the lousing consumer must pay a market rent for the housing he consuines. Indeed, since lousing is not susceptible to the free rider problem that cliaracterizes public facilities, the entrance of new workers into the lousing market does not impose a congestion externality on existing residents.

Nor do linkage fees mitigate encroachment on an implied negative easement. While Nollan ${ }^{207}$ and other implied negative easement cases centered on aesthetic concerns such as scenic views and historic landmarks, it is conceivable that a court might find the protection of existing private lousing residents from rent increases to be a legitimate state interest. ${ }^{208}$ However, the inplication of sucll a holding is an imphed negative easement requiring office dwellers to not compete for housing with existing residents. ${ }^{209}$ Courts would undoubtedly find it unsavory to use the police power to shield existing residents of a commumity from the effects of competition with mconing residents. In any event, the creation of sucli an easement would certainly depart from usual notions of land use regulation, strongly imdicating that linkage prograins do not mitigate an encroachment on a legally cognizable property right.

205. For example, in 1981 , only $9.28 \%$ of the renter-occupied units in the central-city portion of the Boston metropolitan area were publicly owned. U.S. BUREAU OF THE CENSUS, CURRENT HousINg REPORTS, H-170-81-3, Boston, MASS. SMSA Housing Characteristics for Selected Metropolttan Areas, Annual Housing SurveY: 1981 (1984). In 1982, only $14.77 \%$ of the renter-occupied units in the combined cities of San Francisco and Oakland were publicly owned. U.S. BuREAu of THE CENSUS, CuRrent Housing REPORTS, H-170-82-39, SAN Francisco-Oakland, CA SMSA Housing Characteristics for Selected Metropolitan AREAS, ANNUAL Housing Survey: 1982 (1984).

206. There is an argument that low-income housing has some joint consumption characteristics, in that the public derives some benefit from knowing that low-income persons have decent housing. Indeed, the fact that government does provide some housing reflects a recognition of this benefit. See E. SAVAS, supra note 160 , at 47 . However, lousing's individual benefits to the low-income tenant far exceed the public benefits; hence the predominance of the private market in housing production.

207. It is not clear whether the Nollan test would apply to linkage fees at all, for the simple reason that the condition (payment of a fee) does not rise to the level of a per se taking. However, several commentators beheve that the Supreme Court would scrutinize fees just as closely. See, e.g., Falik \& Shimko, supra note 105, at 391-92.

208. Indeed, rent control ordinances accomplisl this very result.

209. The encroacliment on this easement would be the potential competition represented by office dwellers. Thus, the state would be permitted to advance its interest by denying development approval to new office buildings. As an alternative to denial of the permit, the state could require a payment to mitigate the encroachinent on this easement-that is, to provide housing subsidies that would increase supply and reduce competition. 
Again, it is undeniable that increased housing deniand has a negative effect on existing renters. However, this effect does not qualify as an externality. To illustrate, recall that a developer is a producer. Because the production of an office building results (albeit indirectly) in an increased deniand for housing, housing can be seen as an "input," like concrete and glass, in the production of office buildings. An increase in the production of office buildings will thus cause an increase in deniand for housing.

Because the supply of housing, especially in a city with tight controls on new developinent, ${ }^{210}$ is relatively static, the increase in deniand results in an increase in price. The process that takes place in the inarket can be likened to an auction. Rental housing is on the auction block, and existing renters are bidding on it. The developer arrives at the auction and bids the price up higher.

Because existing renters are bidding in the housing auction, the developer inust outbid thein in order to purchase this "input." By doing so, he fully takes into account their preferences when he produces an office building. True, the existing residents are worse off for the appearance of the developer at the housing auction; either they are outbid entirely, or they must pay more for the same amount of housing. However, it is intuitively obvious that the high bidder in an auction cannot be expected to coinpensate the other bidders for this loss.

The effects of the developer's deniand for housing are transnnitted through an efficiently functioning price systein, and there is no externality imposed on existing residents. Instead, displacement and the other effects that the rent increase has on existing renters are known to an econoimist as "price effects," 211 because they are effects transimitted through prices. Indeed, these effects do not entail a benefit to the developer or to office dwellers at all; rather, the increased rents effectively redistribute wealth from existing renters to their residential landlords, who earn more inconie for providing the saine annount of housing. ${ }^{212}$

A new office building produces a multitude of price effects, both positive and negative. For exainple, the owners of neighboring office buildings may suffer a reduction in office rental rates as a result of the conipetition, but that loss is offset by their tenants' gain. If the developer installs a marble facade, the inarket price of inarble is likely to increase soinewhat. This would hurt consumers installing marble bathroonis, but

210. See supra notes $53 \& 54$.

211. Some economists refer to these effects as "pecuniary externalities," but the analysis is the same. See, e.g., W. Baumol \& W. OAtes, The Theory of Environmental Policy: EXTERNAIITIES, Public OUTLAYS AND THE QuALITY OF Life 28-29 (1975).

212. Kaydeu \& Pollard, Linkage Ordinances and Traditional Exactions Analysis: The Connection Between Office Development and Housing, 50 LAW \& CONTEMP. ProBs. 127, 134 (Wiuter 1987). 
would benefit marble suppliers. In fact, indirect price effects will percolate througliout the economy. ${ }^{213}$

Stated simply, new office development causes a price effect in the housimg market that shifts wealth from existing residential renters to their landlords. Rather than taxing the landlords' unearned gam, a linkage fee requires the developer, whose activity merely catalyzed the transfer, to compensate the loser. Because it does not mitigate an externality, the fee thus serves a redistributive function.

Although linkage programs, like other redistributive enactments, may negatively affect efficiency, they are not inherently wrong as long as they reflect society's desire to place distributive concerns above efficiency. However, this important tradeoff should be made not through the amorphous pohice power, but through the tax power, which is specifically defined and limited by statutes and constitutional provisions. ${ }^{214}$

In fact, several states have passed statutes enabling municipalities to levy "excise taxes" on new construction, apparently freeing them to exphicitly advance redistributive goals with development fees. ${ }^{215}$ However, municipalities in other states may be unable to achieve this result. First, the passage of a state statute authorizing the collection of development taxes is invariably subject to deliberations far niore rigorous than those incident to the passage of a local exaction ordinance, and is hence inore difficult to enact.

In addition, development excise taxes are susceptible to judicial concerns over fairness between similarly situated classes of taxpayers. For example, one California court, in allowing the imposition of an "environmental excise tax" and a "business hicense tax" on the "business" of residential construction, held that the legislature had the discretion to exact different taxes from different classes of businesses only when there is a rational basis for that differentiation. ${ }^{216}$

Finally, constitutional tax limitation measures restrain the imposition of such taxes in several states. California's Proposition 13, for exan1ple, requires a two-thirds electoral vote prior to the imposition of

213. See R. MCKean, EFficiency in GOVERNMENT THROUGH Systems ANALYSIS 140-41 (1958) (discussing the complex interdependency of price effects and capital investment).

214. See 16 E. MCQuilin, supra note $48, \S 44.05$, at 12 .

215. These include Arizona, California, Colorado, Kansas, Maine, Maryland, New York, Pennsylvania, and Tennessee. Strauss and Leitner, Financing Public Facilities With Development Excise Taxes: An Alternative to Exactions and Impact Fees, 11 Zoning \& PLAN. L. ReP. 17,19 (1988). The city of Olathe, Kansas has considered imposing an excise tax on land development and subdivision to pay for street construction. Shibley, Development Excise Tax Proposed in Olathe, Kansas, 2 LAND DEV., Spring 1989, at 7.

216. Westfield-Palos Verdes Co. v. City of Rancho Palos Verdes, 73 Cal. App. 3d 486, 495, 141 Cal. Rptr. 36, 43 (1977). But see Associated Homebuilders v. City of Liverniore, 56 Cal. 2d 847, 854, 366 P.2d 448, 452, 17 Cal. Rptr. 5, 9 (1961) (applying the rational basis test in an extremely deferential inanner). 
"special taxes," which would likely include excise taxes. ${ }^{217}$

\section{CONCLUSION}

Recognizing that cities are eager to avoid the many obstacles to the levying of taxes on real estate development, courts and legislatures have provided soine protection from the use of police power exactions to redistribute income. The requirement of a clear nexus between the effect of the development and the use of the exaction will avert many sucli fees. However, in order to eliminate the use of exactions to mitigate price effects, courts slould add an additional requirement: that all regulatory exactions regulate the production of true externalities.

The proposed solution is, however, ouly another finger in a very leaky dike restraining the abuse by states and cities of the police power. Until this vast reservoir of discretion is exphicitly circumscribed, inuincipalities will undoubtedly continue to find creative ways to use discretionary land use authority to extract development value from private property owners and distribute it to the public at large.

217. CAL. CONST. art. XIII A, $\$ 4$ (1978). Since most court decisions agree that a nonregulatory tax levied for a special purpose would constitute a special tax, a linkage "tax" would apparently require two-thirds voter approval. See City \& County of San Francisco v. Farrell, $32 \mathrm{Cal}$. 3d 47, 57, 648 P.2d 935, 940, 184 Cal. Rptr. 713, 718 (1982) ("special taxes" requiring two-thirds majority vote are taxes levied for a specific purpose rather than for general fund); Mills v. County of Trinity, 108 Cal. App. 3d 656, 660, 166 Cal. Rptr. 674, 676 (1980) (fees for regulatory activities that do not exceed the reasonable cost of providing services necessary for the regulatory activities are not “special taxes"); County of Fresno v. Malmstrom, 94 Cal. App. 3d 974, 984, 156 Cal. Rptr. 777, 783 (1979) (special assessments charged under municipal improvement codes are not "special taxes" needing two-thirds voter approval). But cf. City of Westminster v. County of Orange, 204 Cal. App. 3d 623, 251 Cal. Rptr. 511 (1988) (overturning a voter initiative that extended the two-thirds electoral vote requirement to "general" taxes). 
